\title{
Towards the Recognition of Same-Sex Partners in European Union Law: Expectations Based on Trends in National Law
}

\author{
KEES WAALDIJK ${ }^{1}$
}

\section{INTRODUCTION}

TN THE FINAL third of the last century (1.e. since the 1960s), an increase in the legal recognition of homosexuality could be seen in almost all European countries. Four trends appear to be characteristic of this process of legal recognition at the national level (1) steady progress, (11) standard sequences, (111) small change, and (iv) symbolic preparation. The purpose of this chapter is to assess how these trends might also operate at the supranational level of the European Union. The assumption is that a comparative analysis of national legislation may provide useful gurdance about what recognition of same sex partners to expect (and to demand) from the legislative bodies of the European Community - and when.

\section{COMPARATIVE OVERVIEW}

For thirty-six member states of the Council of Europe, I have summarised the process of legal 1ecognition of homosexuality by listing (in the Appendix, Tables 1 and 2, pp. 649-50) the years of the main legislative steps in that piocess. The structure of both tables is based on my perception of the trends of steady progress and of standard sequences (see below). The idea is that almost all (European) countries go, at different tımes and paces, through a standard sequence of steps recognising homosexuality. After decriminalısation (followed or accompanıed by an equalisation of the ages of consent), more or less specific anti-discrimination 
legislation will be enacted, to be followed by legislation institutionalising samesex partnership (and parenthood). ${ }^{2}$

Table 1 ranks the fifteen member states of the European Unıon according to the number of steps they have taken in therr legislation, and according to how long ago a particular country legislated its last step. Table 2 gives a ranking, based on the same criteria, of twenty-one other member states of the Council of Europe. By presenting these two groups of countries separately, it becomes evident that the pattern of legal reform among EU countries is similar to that among non-EU countries.

Both tables are of course a gross simplification. Judicial, admınıstratıve, local and non-governmental forms of (legal) recognition have not been incorporated. In the two columns on criminal law, no distinction has been made between laws only applying to sex between men, and laws also applying to sex between women. Earlier periods of equality in criminal law have not been taken into account. ${ }^{3}$ Legislative recognition of unregistered same-sex cohabitation (eg Hungary) is absent from this overview, as are the possibilities for same-sex couples to have joint authority over the children of one of the partners (eg United Kingdom, the Netherlands, Iceland).

\section{FOUR TRENDS}

The four trends characteristic of the process of legislatıve recognition of different aspects of same-sex love, can be witnessed in so many (European) countries that it is tempting to formulate them as "laws". In the absence of falsification so far, I will indeed speculatively formulate the third and fourth trends as "laws". ${ }^{4}$ The notable exceptions to the first two trends, however, prevent me from phrasing them as general truths.

\section{The Trend of Steady Progress}

Since the 1960s, almost all European countries have made some legislative progress in the legal recognition of homosexuality. The tables in the Appendix show four exceptions to this trend of steady progress. In Greece, the last round of progressive legislation relating to homosexuality took place a little earlier (in 1950). And the other three exceptions (Turkey, Italy and Poland) happen to be

${ }^{2}$ K Waaldık, "Standard Sequences in the Legal Recognıtıon of Homosexuality-Europe's Past, Present and Future", (1994) 4 Australasıan Gay and Lesbian Law Journal 50, "Civil Developments Patterns of Reform in the Legal Recognition of Same-Sex Partners in Europe", (2000) 17 Canadian Journal of Family Law 61

${ }^{3}$ The most recent example of such a period was in Portugal from 1945 untıl 1995 See H Graupner, Sexualitaet, Jugendschutz und Menschenrechte, Tell 2 (Frankfurt, P Lang, 1997) at $597-8$

${ }^{4}$ I hope to challenge readers to try to falsify my hypotheses 
the three European countries with by far the longest uninterrupted history of full equality in criminal law. ${ }^{5}$ In most countries, one step of legislative recognition of homosexuality was followed some years later with one or two other steps in the same direction.

Furthermore, since the 1960s, hardly any country has introduced new ant1homosexual legislation. Luxembourg did so in 1971 by introducing a higher minımum age for homosexual sex, ${ }^{6}$ and Portugal did it (inadvertently) in 1995 by introducing a lower minımum age for heterosexual sex. ${ }^{7}$ The only other example that I know of is the (ineffective) British law of 1988 prohibiting local authorities from "promotıng" homosexuality.

\section{The Trend of Standard Sequences}

A standard sequence may be seen in the typical order of the changes in those countries that do make progress. Legislative recognition of homosexuality starts (most probably after some form of association of homosexuals and information on homosexuality has become legal) with (1) decriminalisation, followed or sometimes accompanied by the setting of an equal age of consent, after which (2) anti-discrimination legislation can be introduced, before the process is finıshed with (3) legislation recognising same-sex partnership and parenting. This trend is quite strong, both inside and outside the European Union. This can be seen in Tables 1 and 2 in the Appendix

- In only thirteen of the thirty-six countries was the decriminalisation of homosexual acts accompanted by the setting of an equal age of consent. ${ }^{9}$ In most countries, the step of decriminalisation was (or will have to be) followed by a later step of equalising the age limits.

- With the exceptions of Ireland and Finland, all countries that have so far enacted anti-dıscrimınation provisions, had decrimınalised homosexual activity and had established equal ages of consent at least three years before. ${ }^{10}$ Furthermore, only four of the twelve countries with equal ages of consent for

5 Tu1key and Italy lead in this way (with 143 and 112 years respectively) Poland (with 69 years) is also far ahead of countries like the Netherlands and Norway

${ }^{6}$ From 1971 unt1l 1992, the minumum age for sex between women or between men was eighteen, whereas the heterosexual age limit was fourteen, since 1992, it has been sixteen for all See Graupner, supran 3, at 531

7 In 1995, the minımum age for heteiosexual sex was lowered from sixteen to fourteen, whereas the homosexual age limit was left at sixteen, Graupner, supra n 3, at 597-8

${ }^{8}$ Local Government Act 1988, s 28 (now only England and Wales, repealed for Scotland in 2000)

9 However, in five of these countries (Nethellands, France, Belgium, Luxembourg and Portugal), different age lımıts were introduced many years after the initial decriminalisation

10 Finland equalised its age limits three years after the introduction of specific anti-discrimmation legislation 
more than a decade, have so far not enacted antı-discrimination provisions Belgium, Poland, Italy and Turkey.

- All twelve countries with some form of national or regional registered partnership legislation in force or in preparation have already equalised their ages of consent in criminal law. And ten of them also have in force national constitutional or legislative anti-discrimination provisions intended to cover sexual orientation. The two apparent exceptions are Belgium and Germany (but see p. 767, and note the provisions in four German Lander). Furthermore, only three of the thirteen countries with such anti-discrimination provisions do not have some form of national or regional registered partnership legislation in force or in preparation Ireland, Luxembourg and Slovenia.

\section{The "Law of Small Change"}

A "law of small change" can be formulated to capture the fact that legislative change on homosexuality is seldom big, legislation advancing the recognition and acceptance of homosexuality only gets enacted if it is perceived as a small change to the law, or if it is sufficiently reduced in impact by some accompanying legislative "small change" that reinforces the condemnation of homosexuality. ${ }^{11}$

\section{The "Law of Symbolıc Preparatıon"}

Finally, I would submit, the process is governed by a "law of symbolic preparatıon". A legal system that has been oppressing homosexuality, will only move to legislation that actually protects and supports lesbian women and gay men, after first passing some symbolic legislation reducing the condemnation of homosexuality (e.g. by advancing its acceptance). The main examples of the working of this law are decriminalisation (which seldom is more than the repeal of criminal rules that were hardly ever applied, because almost all forbidden acts take place in private, or because the authorities had already decided to no longer prosecute under these rules) and antı-discrimination legislation (which mostly consists of rules that are hardly ever applied, because the forbidden grounds often remain undetected and unprovable in the mind of the discriminator, or because the victims of the discrimination frequently have good reasons not to start proceedings).

This is not to say that criminal and anti-discrimination provisions do not have any practical effects. in certain individual cases they will be used, and they will serve generally to deter or justify certain behaviour. It seems that only after decriminalisation and anti-discrimınation legislation have been enacted, will national law-makers pass legislation that is of more direct practical importance to the lives of greater numbers of lesbian women, gay men and their children.

1 For illustrations of thıs "law" at work in the Netherlands, see Waaldık, chap 23 
The primary importance of the intermediate symbolic legislation may well lie in its paving the way for such practical legislation on partnership and parenting. Jurisdictions (and their judges, legislators, and electorates) seem to need time to get used to the idea that homosexuality is neither a crime, nor a good reason for refusing employment or housing.

\section{PREDICTING DEVELOPMENTS IN EUROPEAN UNION LAW}

I will now try to use these four trends and "laws" to predict the process of legal recognition of homosexuality, and especially same-sex partnership, in the European Union as such.

\section{Steady Progress in the European Union}

If most EU countries are making progress in the legal recognition of homosexuality, then it may be assumed that the EU as such will make similar steady progress. Furthermore, the European Parliament repeatedly, ${ }^{12}$ the Commission and Council occasionally, ${ }^{13}$ and the collective of member states once, ${ }^{14}$ have given some evidence that homosexuality is slowly getting more favourable treatment in EC law. All this is not surprising, given the fact that the EU is becoming very much like a European state. The most recent example is Article 21 (Non-discrimination) of the (non-binding) Charter of Fundamental Rights of the European Union (the "EU Charter"): "Any discrimination based on any ground such as sex, race, colour, ethnic or social origin, language, genetic

\footnotetext{
12 See eg "Resolution on sexual discrimination at the workplace", Official Journal (OJ) [1984] C 104/46; "Resolution on equal rights for homosexuals and lesbians in the EC", OJ [1994] C 61/40 (calls on the Commission to draft a Recommendation seeking to end "the barring of lesbians and homosexual couples from marriage or from an equivalent legal framework" and guaranteeing "the full rights and benefits of marriage, allowing the registration of partnerships"); "Resolution on respect for human rights in the European Union (1998-1999)", 16 March 2000, A5-0050/00, http://www.europarl.eu.int/plenary/default_en.htm (" 57 . . . calls on the Member States . . to amend their legislation recognising registered partnerships of persons of the same sex and assigning them the same rights and obligations as exist for registered partnerships between men and women; ... to amend their legislation to grant legal recognition of extramarital cohabitation, irrespective of gender; ... rapid progress should be made with mutual recognition of the different legally recognised non-marital modes of cohabitation and legal marriages between persons of the same sex in the EU"). Sec also p. 725, n. 70.

${ }_{13}$ Notably by including anti-homosexual harassment in the notion of sexual harassment in the non-binding "Commission Recommendation of 27 Nov. 1991 on the protection of the dignity of women and men at work", endorsed by a Council Declaration of 19 Dec. 1991 (OJ [1992] L 49/1, C 27/01). See A Byrne, "Equality and Non-Discrimination" in Waaldijk \& Clapham (eds.), Homosexuality: A European Community Issue (Dordrecht, Martinus Nijhoff Publishers, 1993) 211 at 214-5; M Bell, "Equal Rights and EU Policies", in K Krickler (ed.), After Amsterdam: Sexual Orientation and the European Union (Brussels, ILGA-Europe, 1999) at 30-1, http://www.ilgaeurope.org (Policy Documents). See also infra n.24.

14 By including the ground of "sexual orientation" in the new Art. 13 of the EC Treaty, which empowers the Council to combat discrimination on various grounds.
} 
features, political or other opinıon, religion or belief, membership of a national minority, property, birth, disability, age or sexual onientation shall be prohibited". ${ }^{15}$ Just like other European states, the EU is gradually recognising homosexuality in law.

\section{Following the Standard Sequence?}

If the EU then may be following the trend of steady progress, the expectation should be that it will also follow the standard sequence. Here, the problem is that the EU as such has no history of ant1-homosexual criminal law, because criminal law has generally been a competence of the member states. So for the first steps, we have to look at the individual member states. All have decriminalısed. Eleven have equalised their ages of consent. Four member states still have unequal age limits, ${ }^{16}$ and at least one of them, Austria, is still actıvely using the higher age limit for gay sex to imprison people. ${ }^{17}$ This may not be a total bar to any anti-discrimination or indeed partnership legislation by the EC, after all, Ireland and Finland have shown that anti-discrimination legislation may be enacted before full equality in criminal law has been reached. ${ }^{18}$ Furthermore, the age limit discrimination in the criminal law of two countries is limited (to oral and manual sex in Ireland and to seduction in Greece), and in Portugal the age limit for gay sex is not higher than it is for heterosexual sex in most other countries. $^{19}$

Hopefully, a future ruling of the European Court of Human Rights will establish that age limits in criminal law must not discriminate on the basis of sexual orientation. Such a ruling (most likely in a future case against Austria) ${ }^{20}$ would probably result in a further reduction of the number of member states with discriminatory age limits. And that in turn would help to pave the way for more comprehensive ant1-discrimination measures being unanimously adopted by the Council of the EU.

With a majority of the member states having national anti-discrimination legislation covering sexual orientation by $1997,,^{21}$ the time had come for the

${ }^{15}$ Solemn Proclamation, signed by the Presidents of the European Parliament, the Council, and the Commission in Nice on 7 Dec 2000, OJ [2000] C 364/1 (emphasis added)

${ }^{16}$ Sce App, Table 1

${ }^{17}$ See H Graupner, "Austra", in D West \& R Green (eds), Soctolegal Control of Homosexuality A Multt-Natıon Compartson (Ncw York, Plenum Press, 1997) 269 at 273

${ }_{18}$ See $\mathrm{p} 637$

19 Sec App, Table 1

20 In Sutherland v UK (No 25186/94), the Euiopean Commission of Human Rights has already reached this conclusion (Repoit of 1 July 1997, http //www echı coe int/hudoc) That the European Court of Human Rights will follow the Commission seems likely, given three cases recently decided by the Court Smeth \& Grady v UK and Lusttg Prean o Beckett v UK (27 Sept 1999), Salguetro da Stlva Mouta v Portugal (21 Dec 1999), A D T v UK (31 July 2000) Three challenges to an unequal age lımıt, $S L$ v Austra (No 45330/99), GL v Austra (No 39392/98), and A V v Austrta (No 39829/ 98), were communicated by the Court to the respondent on 30 Jan 2001 Sec Giaupner, chap 30

${ }^{21}$ See App, Table 1 
adoption of EC rules outlawing at least certain forms of discrimination. These could be based on the new Article 13 in the EC Treaty (added in October 1997 and in force since May 1999), which enables the Council (acting unanımously) to prohibit discrimination on eight grounds, including sexual onentation. ${ }^{22}$ The Commission did not waste much time in preparing some implementation of Article 13 on 25 November 1999, it presented a "Proposal for a Council directive establishıng a general framework for equal treatment in employment and occupation", ${ }^{23}$ which would prohibit employment discrimination on all Article 13 EC grounds (including sexual orıentation, but excluding sex, already covered by other dinectives). The proposal made swift progress and was adopted by the Council on 27 November $2000 .{ }^{24}$

This new "Framework Directive" could (together with the no doubt growing number of counti1es with some sort of same-sex partnership legislation) greatly help to prepare the ground for later EC legislation recognising same-sex partnership, in such diverse fields as freedom of movement or the EC staff regulations. The Directive could also provide the much needed extra justification for the Court of Justice to interpret the numerous references in EC law to "spouses" in a less traditional way. ${ }^{25}$ One of the key dynamics of the standard sequence seems to be, that once a jurisdiction has prohibited others (e.g. employers) from distinguishing on the basis of sexual orientation, the legislature and judiciary will have to ask themselves whether it is justifiable that the law itself continues to distinguish on the same, now suspect ground. ${ }^{26}$

\section{Small Change in the EU}

That the EU in this field is following the "law of small change" is only too ev1dent. The first mention of homosexuality in a legal anti-discrimination document can be found in the explanatory part of the non-binding "Commission Recommendation of 27 November 1991 on the protection of the dignity of

\footnotetext{
22 See M Bell, "The New Aiticle 13 EC Tieaty A Sound Basis for European Anti-Discimination Law", (1999) 6 Maastricht Journal of European and Comparatwe Law 5, L Flynn, "The Implications of Atticle 13 EC-Afte Amsterdam, Will Some Forms of Disciimination Be More Equal than Otheis"”, (1999) 36 Common Market Law Revtew 1127 See also Krickler, supra n 13

23 COM (1999) 565, O] [2000] C 177 E/42 See Bell, chap 37

24 Council Dir 2000/78/EC of 27 Nov 2000 establishing a general framework for equal treatment in employment and occupation, OJ [2000] L 303/16 Two grounds (racial o1 ethnic origin) were deleted because they were covered by a separate directive See $\operatorname{tnf}$ ra $\mathbf{n} 33$

25 At the very least, any distunction between married heterosexual spouses and homosexual reg isteied paitneis should be classified as a distinetion based on scxual orientation The first chance for the Court of Justice to i ule on this point came when it had to decide $D$ v Counctl, Cases C 122/99 P, C $125 / 99$ P (appeals from a 28 Jan 1999 decision of the Court of First Instance in Case T-274/97, in his Opinion of $22 \mathrm{Feb} 2001$, Advocate General Mischo urged the Court of Justice to dismiss the appeals, the Court of Justice agieed in its Judgment of 31 May 2001, see Conclusion, pp 767-69) See also Bell, chap 37, L Flynn, "Equality between Men and Women in the Court of Justice", in Eeckhout \& Tridimas (eds), (1998) 18 Yearbook of European Law 259 at 285-26

'G See Waaldijk (2000), supra n 2, at 85
} 
women and men at work". ${ }^{27}$ What followed were facllities for same-sex partners of European Parliament staff to use restaurants and language courses. ${ }^{28}$ And the new anti-discrimination clause in the Staff Regulation does indeed include the ground of sexual orientation. ${ }^{29}$ However, the clause renders itself virtually meaningless with regard to the partners of gay and lesbian staff by providing that distinctions based on marital status are unaffected. ${ }^{30}$

These small changes indicate that it is more than probable that EC legislation protectıng or supporting lesbian women and gay men will take relatively short steps, reflecting the caution or prejudice of perhaps only a few of the many indviduals and countries involved in producing EC rules. The new Article 13 of the EC Treaty itself, although politically important, is already an example of that it is only an enabling clause, it has no direct effect, it can only be implemented by a unanimous Council, and the ground of sexual orientation is not accompanied by that of civil status. ${ }^{31}$ Similarly, Article 21 of the new EU Charter is not binding.

Of the first two directives adopted by the Council on the basis of Article 13 EC, only the Framework Directive deals with sexual orientation discrimination, and that directive only covers the field of employment. ${ }^{32}$ That restriction is in sharp contrast with the much wider directive prohibiting racial discrimination in employment, social security, healthcare, education, and the provision of goods and services, including housing (the "Race Directive"). ${ }^{33}$ And the potentral impact of the Framework Directive may be further reduced by the following preces of "small change"

- As to the ground sexual orentation, the Commission's explanatory memorandum claims that "a clear dividing line should be drawn between sexual orientation, which is covered by this proposal, and sexual behaviour, which is not". ${ }^{34}$ This is of course a nonsensical claim. no such dividing line can be made, because in most cases of anti-homosexual discrimination, the difference of treatment is based on the sexual onentation of certain behaviour. Hardly anyone will be denied employment because he or she has had sex (or lives) with another person, nor because of his or her unexpiessed sexual preferences the denial of employment will far more often be based on the sexual orientation of the sexual activity or on the sexual orientation of the

27 See supra 13

${ }_{28}$ On $25 \mathrm{Feb} 2000$, a similar measure was adopted at the Court of Justice non pecuniary spousal benefits are now avalable to unmarried (same-sex or different sex) partners of employees of the Court A more generous scheme, inciudng pecuniary benefits such as pension cntitlements, was adopted on 17 Aug 1995 at the European Monctary Institute in Fiankfuit, and subsequently at the European Central Bank

2) Council Regulation 781/98 of 7 April 1998, OJ [1998] L 113/4, Att 1a

30 See Bell, supra n 13 , at 31

31 Sec supran 22

${ }^{32}$ Sec supran 24

${ }^{33}$ Council Dir 2000/43/EC of 29 Junc 2000 implementing the principle of equal treatment betwecn persons itrespective of 1acial o1 ethnic onigin, OJ [2000] L 180/22, Art 3

34 Supran 23, para 5 at A1t 1 
cohabitation, i.e. on the fact that the person's behaviour was oriented towards someone of the same sex. ${ }^{35}$ Nevertheless, the statement in the explanatory memorandum could be (wrongly) interpreted (at the national level) as implying that employers will be allowed to continue discrimination against practising homosexuals. Fortunately, the Court of Justice does not use explanatory memoranda when interpreting directives.

- The explanatory memorandum also claims that "this proposal does not affect marital status and therefore it does not impinge upon entitlements to benefits for married couples". ${ }^{36}$ Preambular paragraph 22 repeats this claim: "This Directive is without prejudice to national laws on marital status and the benefits dependent thereon." This claim is in direct contradiction to the proposed prohibition of indirect discrimination. It is evident, in the words of Article 2(2) of the Directive, that the "apparently neutral" criterion of marital status "puts ... at a particular disadvantage" gay and lesbian couples, because they are barred from marriage. Of course, neither the explanatory memorandum nor the preamble can introduce an exception to the operative part of the Directive. Nevertheless, these statements could be (wrongly) interpreted as implying that employers will be allowed to continue the most common form of indirect anti-homosexual discrimination-even if there is no objective justification for it.

- Article 4(2) of the Directive allows for an exception for "public or private organisations the ethos of which is based on religion or belief". Under certain conditions such organisations would then be permitted to base a difference of treatment on "a person's religion or belief" (but not another ground), ${ }^{37}$ and "to require individuals working with them to act in good faith and with loyalty to the organisation's ethos." Applying the "loyalty to the ethos" requirement, certain religious organisations could claim to have the freedom to continue discriminating against lesbians and gay men.

These three, dangerously vague, potential restrictions of the proposed prohibition of sexual orientation discrimination in employment seem to have been politically necessary to achieve the unanimous adoption of the directive as a whole.

\footnotetext{
35 In view of Grant v. South-West Trains, Case C-249/96, [1998] European Court Reports I-621, it will be difficult to deny that to discriminate between same-sex and different-sex partners is indeed sexual orientation discrimination. Under the Dutch General Equal Treatment Act, the main problems of anti-homosexual discrimination are in fact related to the non-availability for same-sex couples of marital status and marital advantages: since 1994, two-thirds of the more than thirty-five "homosexual cases" brought beforc the Equal Treatment Commission have been about such partner-discrimination. See http://ruljis.leidenuniv.nl/user/cwaaldı//www/ (overview in Dutch).

36 Supra n.23, para. 5 at Art. 1.

37 The Commission's orıginal proposal permitted discrımınation based on a "relevant characteristıc related to religion or belief", which seemed capable of being interpreted as covering sexual orientation. 1 bid., para. 5 at Art. 4.
} 


\section{Symbolic Preparation for Further Reforms in EU Law}

As far as the "law of symbolic preparation" is concerned, the question must be whether the EU can properly be called a legal system that has been oppressing homosexuality. I think it can. Firstly, the EU is manly the continuation, in a growing number of fields, of national legal systems that have oppressed homosexuality in many ways, and that are only slowly replacing the oppression with some recognition. Secondly, the directives and regulations of the EC are full of references to "marriage" and "spouse", thus excluding all homosexual partners from various advantages in many fields, especially that of free movement. ${ }^{38}$ In a sense, the EC has its own - very traditional and therefore exclusively heterosexual-family law. Therefore, it may well be necessary to get some symbolic preparation enacted, before this legal system is up to the task of replacing its oppression with recognition.

As mentioned above, some such symbolic legislation has already been enacted in the context of the EC. Article 13 of the EC Treaty "stands out as conspicuously and delıberately neutered". ${ }^{39}$ Nevertheless, the process of adopting the text of Article 13, including the words "sexual orientation", may have served to get the member states used to the 1dea that in the context of the EC they will occasionally have to address the rights of lesbian women and gay men. Thus, Article 13 "which at present stands as a rhetorical gesture may unexpectedly give additional content to the concept of (European) citizenship". ${ }^{40}$ The rather limited Framework Directive on employment discrimination, and the non-binding Article 21 of the EU Charter, will serve as further symbolic legislation, preparing the field for more practically relevant laws. For example, it remains to be seen whether enough political power can be mobilised to make the Framework Directive as strong as the Race Directive, and whether the Framework Directive will (some day) be interpreted as prohıbitıng indirect discrimination via the so-called "neutral" criterion of marital status. ${ }^{41}$

For the European Union itself, opening up marriage or introducing registered partnership is not an option, because it has no competence relating to civil status in particular or family law in general, which is left to the member states. ${ }^{42}$

38 The Dutch Government's "Commission on the openung up of civil marriage to persons of the same sex" made an inventory of EC regulations and directives explicitly referring to "marriage" or "spouse" In its report (Rapport Commissie inzake openstelling van bet burgerlyk buwelik voor personen van betzelfde geslacht, The Hague, Ministry of Justıce, Oct 1997, at 34), it produced a list of seventeen such regulations and twenty four such directıves from veiy diverse fields, including the free movement of persons (notably Councl Regulation 1612/68/EEC), social security, tax law, employment, agriculture (including Commission Regulation 2568/91/EEC on olive oil), fisheries (including Council Dir 78/659/EEC on water quality for fish), transport (including Commıssion Dir $91 / 662 / \mathrm{EEC}$ on the behaviour of the steering wheel), and insurance

39 Flynn, supra $\mathrm{n} 22$, at 1133

40 lbid, at 1151-2

41 See $\mathrm{p} 643$

42 The institutions of the EU cannot provide EU citizens with a civil status (more or less equivalent to marriage) However, as employers, the institutions of the EC could establish a register of staff 
Therefore, there are three forms of partner-discrımınation which can be elıminated by-and in-EC law:

(1) discrumination between unmarned different-sex partners and unmarried same-sex partners (direct discrimination on the basis of sexual orientation);

(2) discrimination between married different-sex spouses and registered same-sex partners (direct or indirect discrimination on the basis of sexual orientation); 43

(3) discrimination between married different-sex spouses and unmarried same-sex partners (indırect discrimination on the basis of sexual orientation).

The third form represents the biggest problem in most countries. However, if full equality (in employment) between unmarried same-sex couples and married different-sex couples remains too big a step for the Court of Justice, in interpreting the Framework Directive, then at least the other two forms of partnerdiscrimination need to be included in it. Both inclusions will be only of limited application in most member states (because they do not recognise unmarried different-sex partners or do not have registered partnershıp for same-sex partners), but they would be highly relevant as symbolic preparation for adjusting EC legislation to the existence of same-sex couples. This would lead to two principles to be incorporated in the interpretation of the Framework Directive:

- Princtple 1 (Employment). Where an employer provides spousal benefits to the unmarried different-sex partner of an employee, this employer should provide the same benefits to the unmarred same-sex partner of an employee.

(This of course is the principle that the Court of Justice refused to adopt, applying EC sex discrimination law, in Grant v. South-West Trains. ${ }^{44}$ ) This principle would only affect employers who are both too modern to deny the existence of heterosexual cohabitation, and too traditional to recognise gay and lesbian cohabitation. The huge majority of employers in Europe are

who have registered their unmarried partner for the purposes of claiming "spousal" rights and obligations under the Staff Regulations. See chap. III.1, Commission's consultative document of 29 Nov. 2000, SEC(2000)2085/4, discussed in Egalté Newsletter, Issue 31, Winter 2001, pp. 3-4). The EC has also entered the field of "free movement of civ1 status" through Council Regulation 1347/2000/EC of 29 May 2000 on jurisdiction and the recognition and enforcement of judgments in matrimontal matters and in matters of parental responsibility for children of both spouses.

${ }^{43}$ A fourth form of discrimination could emerge, if any national body or an EC institution refused to recognise a same-sex marriage (c.g., one contracted in the Netherlands) as equivalent to a different-sex marriage.

${ }^{44}$ Supra n.35. The Court misstated the issue in that case when it. "considered the position of unmarried same-sex couples in relationship to unmarried and married opposite-sex couples, where in fact, the only circumstance directly relevant to this case was the position of unmarried oppositesex and unmarried same-sex couples. Lisa Grant's claim was centred on the fact that other unmarned couples enjoyed the travel concession". M Bell, "Shifting Conceptions of Sexual Discrimination at the Court of Justice. From P v. S to Grant v. SWT", (1999) 5 European Law Journal 63 at 72. 
probably either more modern, or more traditional than that. ${ }^{45}$ So they would not be bothered by this interpretation of the Framework Directive. ${ }^{46}$

- Principle 2 (Employment). Where an employer provides benefits to the married different-sex partner of an employee, this employer should provide the same benefits to the registered (or married) same-sex partner of an employee.

(This of course is the issue which the Court of Justice had to address in D.v. Council. ${ }^{47}$ ) This principle would only affect employers who happen to employ persons who have already registered with (or married) their same-sex partners, e.g. in a Nordic country or the Netherlands. ${ }^{48}$ For most employers in other countries, it will be some time before this will be the case. However, given the Grant judgment, it can hardly be denied that to distinguish between different-sex marriage and same-sex registered partnership (or marriage) is (direct) discrimination on the basis of sexual ortentation.

Then at some later stage the third principle could be added:

- Principle 3 (Employment). Where an employer provides benefits to the marned different-sex partner of an employee, this employer should prounde the same benefits to the partner of an employee who cannot marry the employee because they are of the same sex, and cannot register with the employee because there is no registered partnership legislation.

It will then be up to the employer whether or not to provide the same benefits also to the unmarried different-sex partner of an employee who has chosen not to marry. Alternatively, employers could be required (by European or national law) to give equal treatment to married and all unmarned couples (1.e. including different-sex cohabitants).

Once Principles 1 and 2 (and perhaps 3 ) have been incorporated into the interpretation of the Framework Directive, the time will definitely have come to start amending (or re-interpreting) all the EC regulations and EC directives that favour married spouses. Because there are no EC rules that favour different-sex cohabitees over same-sex cohabitees, it will not be necessary to first apply Principle 1 to those regulations and directives. The incorporation of Principle 1 into the interpretation of the Framework Directive should make it politically possible to prevent spousal benefits in EC rules from being extended to heterosexual unmarried partners only.

In the absence of a move towards full equal treatment of married and unmarried partners (Princıple 3), the process of amending or interpreting all those EC

45 See pp 642-43

${ }^{46}$ For this reason (and because Grant was only about equal pay and not about other aspects of employment), I would disagree with M Bell (supra n 44, at 75, 79) and L Helfer ((1999) 93 American Journal of International Law 200 at 203), who have both argued that Grant may have been lost because the Court was asked to do too much

47 Supra n.25

${ }^{48}$ For numbers of registered partners, see Waaldıjk, chap 23, App VI 
rules could therefore cautrously start with Principle 2 (countering the second form of partner-discrimination)

- Principle 2 (All EU Law). Where a directive or regulation provides for a benefit for marred spouses, it should be interpreted as applying to same-sex marred spouses, and interpreted or amended so as to make that benefit avalable to registered partners.

That principle will probably be first applied to the staff regulations of the EC, because there the parallel with the Framework Directive is most evident. After that, the various dilectives and regulations in the economic field could be adjusted..$^{49}$ Obviously, such an extension of partnership rights would be more controversial in some fields of EC law than in others. The immigration rights of the registered same-sex partners of EU citizens (and especially of non-EU citizens) may well be the last to be recognised. ${ }^{50}$

Until Principle 2 is incorporated into most EC rules, it would seem unlikely that Principle 3 would be applied to them. Principle 2 is far less controversial, because it simply reflects and respects changes in national family law, which are taking place as and when a member state feels ready to make a quasi-marital civil status avalable to same-sex couples. The recognition of same-sex registered partnerships (and marriages) in EU law would be a good incentive for other countries to create such a status for their own citizens, without encroaching on the competence of the Member States in the field of family law. However, because it seems improbable, in the next ten years, that every member state will legislate some form of partnership registration, the third principle will remain necessary to guarantee full equality for all European citizens in same-sex relationships. So the final step in recognising same-sex partners would need to be the incorporation of Principle 3 in all fields of EU law.

- Principle 3 (All EU Law). Where a directive or regulation provides for a benefit for married spouses, it should be interpreted or amended so as to make that benefit also avalable to partners who cannot marry each other because they are of the same sex, and cannot register as partners because there is no equivalent-to-marriage registered partnership legislation.

Obviously one way to incorporate that principle would be to extend the benefits to all (same-sex and different-sex) cohabitants.

\section{CONCLUSION RECOGNISING THE RECOGNITION OF SAME-SEX PARTNERSHIPS}

One of the many ways in which the European Union resembles its member states is in its tradition of having numerous special rights for heterosexual couples.

\footnotetext{
49 See supra $\mathrm{n} 38$

50 See K Waaldık, "Towards Equality in the Freedom of Movement of Persons", in Krıckler, supran 13,40 at $46-7$
} 
However, the EU also mirrors those member states in having slowly started to legally recognise homosexuality. The fact that four member states have not yet fully completed the decriminalisation of homosexual activity could slow down progress in the EU. Nevertheless, like the majority of member states, the EU has started on the road of explicit prohibition of anti-homosexual discrimination. An important, but largely symbolic step, was the inclusion of sexual orientation as a non-discrimination ground in Article 13 of the EC Treaty. The first directive implementing the non-discrimination principle of Article 13 with respect to sexual orientation, the Framework Directive, is only a small step because of its limited scope (although it is certainly of great symbolic importance). Whether the Directive will be interpreted by the Court of Justice as covering all direct and indirect discrimination between same-sex and different-sex partners is uncertain. If not, amending directives will be necessary to extend its scope to equality between same-sex and different-sex cohabitants, between married spouses and registered partners, and eventually between married spouses and unmarried/ unregistered same-sex partners.

Full recognition of same-sex partners in fields other than employment seems even further away, especially with respect to free movement of persons. It seems likely that here, too, the EU will follow the standard sequence followed by the member states: only after making it unlawful for (private) employers to discriminate on the basis of sexual orientation will the legislative bodies start to scrutinise their own products for distinctions on the same ground. Almost all anti-homosexual discrimination contained in EC regulations and directives takes the form of special benefits for married spouses. It 1s submitted that these numerous regulations and directives could first be extended, by interpretation or amendment, to cover registered (and married) same-sex partners; in other words, the EU should first recognise any national recognition of same-sex partnerships. Thus, the EU would be merely reflecting the changes that are takıng place in the family law of a growing number of member states. And then at a later stage, a more comprehensive revision of $\mathrm{EC}$ regulations and directives could become feasible: extending all spousal benefits to all partners who cannot marry each other because they are of the same sex, and cannot register as partners because there is no equivalent-to-marriage registered partnership legislation. 


\section{APPENDIX \\ HISTORICAL OVERVIEW OF THE MAIN LEGISLATIVE STEPS IN THE LEGAL RECOGNITION OF HOMOSEXUALITY IN EUROPEAN COUNTRIES}

This overview is based on the hypothesis that almost all countries go, at different times and paces, through a standard sequence of legislative steps recognising homosexuahty. ${ }^{51}$

\section{Symbols Used}

$1993=$ ycar in which the legislation came into force

$\langle 1993\rangle=$ limıted or implicitly worded legislation

[1993] = legislation applying in part(s) of the country only

i.p. = legislation in preparation or not yet in force

\section{Table 1 EU Member States}

\begin{tabular}{|c|c|c|c|c|c|c|}
\hline & $\begin{array}{l}\text { Decriminal- } \\
\text { isation of male } \\
\text { (+ female) } \\
\text { homosexual } \\
\text { acts }\end{array}$ & $\begin{array}{l}\text { Equalisation } \\
\text { of age limits } \\
\text { in sex } \\
\text { offences }\end{array}$ & $\begin{array}{l}\text { Specific antı- } \\
\text { discrimination } \\
\text { legislation }\end{array}$ & $\begin{array}{l}\text { Registered } \\
\text { partnership } \\
\text { legislation }\end{array}$ & $\begin{array}{l}\text { Joint or } \\
\text { second- } \\
\text { parent } \\
\text { adoption }\end{array}$ & $\begin{array}{l}\text { Civil } \\
\text { marriage }\end{array}$ \\
\hline Netherlands & 1811 & 1971 & $\begin{array}{l}(1983) \\
1992,1994^{53}\end{array}$ & $1998^{52}$ & 2001 & 2001 \\
\hline Denmark & 1930 & 1976 & $1987,1996^{54}$ & 1989 & 1999 & - \\
\hline Sweden & 1944 & 1978 & $1987,1999^{55}$ & $1995^{56}$ & $1 \mathrm{p}$. & - \\
\hline France & 1791 & 1982 & $\begin{array}{l}(1985,1986) \\
1 \mathrm{p} .57\end{array}$ & (1999) & - & - \\
\hline Germany & {$[1968], 1969^{58}$} & [1989], 1994 & $\begin{array}{l}{[1992,1993} \\
1995,1997]^{59}\end{array}$ & $(2001)$ & - & - \\
\hline Spain & 1822 & $1822^{60}$ & 1995 & $\begin{array}{l}{[(1998,1999} \\
2000,2001)]^{62}\end{array}$ & {$[1 \mathrm{p}]^{61}$} & - \\
\hline Finland & 1971 & 1998 & 1995 & 1.p. & - & - \\
\hline Luxembourg & 1792 & 1992 & 1997 & - & - & - \\
\hline Ireland & 1993 & $-m^{63}$ & $\begin{array}{l}(1989), 1993 \\
1998,2000^{64}\end{array}$ & - & - & - \\
\hline Belgium & 1792 & 1985 & - & $(2000)$ & - & $1 \mathrm{p}$ \\
\hline Italy & $1889^{65}$ & 1889 & - & - & - & - \\
\hline UK & $\begin{array}{l}{[1967,1980]} \\
1982^{66}\end{array}$ & 2001 & - & - & - & - \\
\hline Portugal & 1945 & -67 & - & $-^{68}$ & - & - \\
\hline Greece & 1950 & $-^{69}$ & - & - & - & - \\
\hline Austria & 1971 & - & (1993) & - & - & - \\
\hline
\end{tabular}




\section{Table 2 Other Council of Europe Member States ${ }^{70}$}

\begin{tabular}{|c|c|c|c|c|c|}
\hline & $\begin{array}{l}\text { Decruminal- } \\
\text { isation of male } \\
\text { (+ female) } \\
\text { homosexual } \\
\text { acts }\end{array}$ & $\begin{array}{l}\text { Equalisation } \\
\text { of age limits } \\
\text { in sex } \\
\text { offences }\end{array}$ & $\begin{array}{l}\text { Specific ant1- } \\
\text { discrimination } \\
\text { legislation }\end{array}$ & $\begin{array}{l}\text { Registered } \\
\text { partnership } \\
\text { legislation }\end{array}$ & $\begin{array}{l}\text { Joint or } \\
\text { second- } \\
\text { parent } \\
\text { adoption }\end{array}$ \\
\hline Iceland & $1930^{71}$ & 1992 & 1996 & 1996 & $2000^{72}$ \\
\hline Norway & 1972 & 1972 & 1981,1998 & 1993 & - \\
\hline Slovenıa & 1977 & 1977 & 1995 & - & - \\
\hline Czech Rep & 1961 & 1990 & 2001 & $1 \mathrm{p}$ & - \\
\hline Switzerland & $1942^{73}$ & 1992 & $(1999)^{74}$ & $\begin{array}{l}[(2001)]]^{75} \\
1 \mathrm{p}\end{array}$ & - \\
\hline Turkey & 1858 & 1858 & - & - & - \\
\hline Poland & 1932 & 1932 & - & - & - \\
\hline Malta & 1973 & 1973 & - & - & - \\
\hline Slovakıa & 1961 & 1990 & - & - & - \\
\hline Ukraine & 1991 & 1991 & - & - & - \\
\hline Russia & 1993 & 1997 & - & - & - \\
\hline Latvia & 1992 & 1998 & - & - & - \\
\hline Estonıa & 1992 & $1 \mathrm{p}$ & - & - & - \\
\hline Lithuanıa & 1993 & ${ }^{\mathrm{t} p}$ & $1 \mathrm{p}$ & - & - \\
\hline Hungary & 1961 & - & (1997) & $-{ }^{77}$ & - \\
\hline Romama & 1996 & - & $(2000)^{7 c}$ & - & - \\
\hline Bulgarıa & 1968 & - & - & - & - \\
\hline Croatıa & 1977 & - & - & - & - \\
\hline Moldova & 1995 & - & - & - & - \\
\hline Albanıa & 1995 & - & - & - & - \\
\hline Cyprus & 1998 & - & - & - & - \\
\hline
\end{tabular}

${ }^{51}$ See supra n.2 and pp. 637-38. A general source for the information in this table is the World Legal Survey of the International Lesbian and Gay Association, http/twww.llga.org, as well as ILGA-Europe's monthly EuroLetter, http//met.unı2.dk/ steff/eurolet.htm. See also Graupner, supra n.3, at 361-759, and "Sexual Consent The Cruminal Law un Europe and Overseas", (2000) 29 Archives of Sexual Behavior 415 (decriminalisation), R Wintemute, Sexual Ortentation and Human Rights (Oxford, Oxford University Piess, 1997) at vi11, xi, 265-6 (anti-discrimination legislation) (updated in Appendix II to this book), the othei chapters in this book (partnership and adoption) Corrections and additions are alwayswelcome (c.waaldıjk@law leıdenuniv.nl).

${ }^{52}$ Unregistered cohabitation has received legislative recognition since the late 1970s. See Waaldıjk, chap. 23.

${ }^{33}$ In the prohibition of discrimination in Art. 1 of the Dutch Constitution, which entered into force in 1983, the words "or any ground whatsoever" were added with the explicit intention of covering discrimination based on homosexual onentation (see K Waald 1 k, "Constitutional Protection Against Discrimination of Homosexuals", (1986/1987) 13 Journal of Homosexualty 57 at 59-60) In 1992, "hetero- or homosexual orientation" was inserted in several anti-discrimination provisions of the Penal Code. In 1994, the General Equal Treatment Act came into force, covermg several grounds including "hetero- or homosexual orientation" (see Appendix II, p. 786).

${ }_{54}$ Anti-discrimination legislation extended to cover employment discrimination in 1996.

${ }_{55}$ Ant1-discrimination legislation extended to cover employment discrimination in 1999. 
${ }^{56}$ Legislation on unregistered cohabitation came into force in 1988. See Ytterberg, chap. 22.

57 With the intention of coverung sexual orientation discrimination, the word "moeurs" (morals, manners, customs, ways) was inserted in several anti-discrimination provisions of the Penal Code (1985) and of the Labour Code (1986). "Sexual ortentation" is expected to be added in 2001. See Appendix II, p. 784.

58 In the former German Democratic Republic (East Germany), homosexual acts between men were decriminalısed in 1968, and the age limits were equalısed in 1989. In the pre-unification Federal Republic of Germany (West Germany), the dates were 1969 and 1994. See Graupner, supra n.3, at $407-10$.

59 Anti-discrimination provisions specifically referring to sexual orientation have been included in the constitutions of three Lander (states) Brandenburg (1992), Thuringia (1993) and Berlin (1995). Anti-disciumination legislation has been enacted in at least one Land Saxony-Anhalt (1997).

6n Although the formal age limits for heterosexual and homosexual acts were equalsed at the tıme of decriminalisation of homosexual acts in 1822, in practice homosexual acts with minors continued to be penalısed untıl 1988 under a general provision aganst "sei rous scandal and indecency" (see Graupner, supra n.3, at 665-6).

61 The provisions on joint adoption by unmarried different-sex and same-sex couples have been suspended pending a challenge to the constututional power of Navarıa (vs. the national government) to enact them. Sec Pérez Cánovas, chap. 26.

62 Limited registered partnership legislation has so far only been enacted in four regions Catalona (1998), Aragon (1999), Navaria (2000) and Valencia (2001).

${ }^{63}$ For oral and non-penetrative sex, the age limit is higher for male homosexual acts (17) than for heterosexual and lesbian acts (15). Since decrimmalisation in 1993, the age limit for male homosexual anal sex and for heterosexual vaginal and and sex is equal at 17. See Graupner, supra n.3, at 481, 487.

${ }_{64}$ In 1989 , only incitement to hatred was prohibited. Discrimınatory dismıssal became unlawful in 1993, other employment discrimination in 1998, and discrimination in education, housing, goods and services in 2000.

${ }^{65}$ In several parts of Italy decrimunalisation of sex between men took place beforc 1889 (e.g. in 1861 in the Neapolitan province). See Graupner, supra n.3, at 505, and F Leroy-Forgeot, Histotre jurtdque de l'homosexualté en Europe (Parıs, Presses Universitares de France, 1997) at 66.

${ }_{66}$ Decriminalisation of most sex between two men over 21 took place in England and Wales in 1967, in Scotland in 1980 and in Northern Ircland in 1982 (see Graupner, supra n.3, at 711, 727, 739).

67 Sce supra n.3.

68 Legislation on unregistcred cohabitation came into foice in 2001. See p. 762.

69 In the case of "seduction", the age limit for sex between men is higher (17) than for lesbian or heterosexual sex (15). See Graupner, supra n.3, at 466.

70 Table 2 docs not include Andorra, Armenia, Azcrba1jan, Georgia, Liechtenstem, Macedonia and San Marmo, as well as three European states which have yet to join the Council of Europe (Belarus, Bosnia-Herzegovina, Serbia-Montenegro).

71 Graupner (supra n.3, at 491) assumes that decrimınalısatıon took place in the same year as in Denmark (1930). From 1918 until 1944, Iceland was an independent Kingdom in personal union with the Kingdom of Denmark.

${ }^{72}$ On 8 May 2000, the Icelandic Parliament passed an amendment allowing a person in a registered partnership to adopt the child of his or he1 registered partner. See EuroLetter, supra n.51 (No. 80 , June 2000).

${ }_{73}$ In five Swiss cantons, sex between men had bcen decrimunalssed before the entering into force of the first natronal Penal Code in 1942. See Graupner, supra n.3, at 640.

${ }^{74}$ Since 1999, the Swiss Constitution has included "way of life" ("mode de vie", "Lebensform", "modo divta") in the list of giounds in its non-discrimination clause, which is intended to cover "sexual orientation".

75 The canton of Geneva adopted a lımıted registered partncrship law in 2001.

76 Executivc ordinance only.

77 Hungary does have legislation on unregistered same-sex cohabitation. See Farkas, chap. 31. 